\title{
Effect of post weld heat treatment on wear resistance of hot forging cast steel die coated with surfacing layer
}

\author{
Wujiao $\mathrm{Xu}^{\mathrm{a}}$, Xin Ma, Nongjie Tang, Li Zhu, Wuhua Li, and Yongfeng Ding \\ College of Material Science and Engineering, Chongqing University, 400044 Chongqing, China
}

\begin{abstract}
The wear resistance capability of die surfacing layer under different Post Weld Heat Treatments (PWHT) was analysed by Finite Element Method (FEM) simulation and experiments. Taking the hot forging process of crankshaft as example, a wear model of hot forging die coated with surfacing layer was established by the software DEFORM-3D. The simulation results indicate that the wear resistance capability of the die surfacing layer is optimal when tempering temperature and holding time are $550{ }^{\circ} \mathrm{C}$ and $4 \mathrm{~h}$ respectively. To verify the wear calculation result, 16 groups of different PWHT orthogonal wear tests were performed under atmospheric condition at $400^{\circ} \mathrm{C}$. The wear test result shows a good agreement with the FEM simulation result. SEM observation of the wear debris shows that oxidative wear plays a dominant role in $400^{\circ} \mathrm{C}$ among 16 specimens. Furthermore, when tempering temperature and holding time are $550^{\circ} \mathrm{C}$ and $4 \mathrm{~h}$ respectively, the alloy carbide dispersively distributes in the metallographic structure, which can improve the wear resistance of the surfacing.
\end{abstract}

\section{Introduction}

In a hot forging process, Complex loading conditions simultaneously cause different types of die failure such as wear, plastic deformation, fatigue. etc, among which wear accounts for $70 \%$ of all the hot forged die failure [1]. Considering the requirement of the hot forging process and die cost, the die construction of casting-steel substrate coated with the surfacing layer is adopted in this work.

In a hot forging process, Complex loading conditions simultaneously cause different types of die failure such as wear, plastic deformation, fatigue. etc, among which wear accounts for $70 \%$ of all the hot forged die failure [1]. Considering the requirement of the hot forging process and die cost, the die construction of casting-steel substrate coated with the surfacing layer is adopted in this work.

\section{Die material used}

To study the wear resistance of hot forging cast-steel die coated with surfacing layer, gas metal arc welding with $545 \mathrm{E}$ flux cored wires was employed in surfacing welding. The cast-steel substrate is made of $\mathrm{ZG} 25 \mathrm{MnCrNiMo}$. The welding current and voltage were $130 \mathrm{~A}$ and $26 \mathrm{~V}$ respectively.

\footnotetext{
${ }^{\text {a }}$ Corresponding author: xuwujiao_cq@163.com
}

This is an Open Access article distributed under the terms of the Creative Commons Attribution License 4.0, which permits unrestricted use, distribution, and reproduction in any medium, provided the original work is properly cited. 
Table 1. Chemical composition of the casting-steel substrate and surfacing layer (wt.\%).

\begin{tabular}{|c|c|c|c|c|c|c|c|c|c|c|}
\hline Chemical composition & $\mathbf{C}$ & $\mathbf{S i}$ & $\mathbf{M n}$ & $\mathbf{P}$ & $\mathbf{S}$ & $\mathbf{C r}$ & $\mathbf{N i}$ & $\mathbf{M o}$ & $\mathbf{C u}$ & $\mathbf{F e}$ \\
\hline ZG25MnCrNiMo & 0.27 & 0.53 & 1.37 & 0.02 & 0.01 & 0.55 & 0.43 & 0.27 & 0.10 & 97.57 \\
\hline 545E & 0.10 & 0.77 & 0.83 & 0.008 & 0.007 & 11.32 & 2.12 & 2.43 & - & 82.42 \\
\hline
\end{tabular}

Table 2. The mechanical properties of the casting-steel substrate and surfacing layer.

\begin{tabular}{|c|c|c|c|c|c|}
\hline $\begin{array}{c}\text { Die } \\
\text { material }\end{array}$ & $\begin{array}{c}\text { Young modulus } \\
\text { E (GPa) }\end{array}$ & $\begin{array}{c}\text { Poisson } \\
\text { ratio v }\end{array}$ & $\begin{array}{c}\text { Hardness } \\
\text { (HRC) }\end{array}$ & $\begin{array}{c}\text { Coefficient } \\
\text { of Friction }\end{array}$ & $\begin{array}{c}\text { Yield stress } \\
\boldsymbol{\sigma}_{\mathbf{0 . 2}}(\mathbf{M P a})\end{array}$ \\
\hline ZG25MnCrNiMo & 42.5 & 0.3 & 24 & - & 512 \\
\hline $545 \mathrm{E}$ & 27.6 & 0.3 & 48 & 0.2 & 588 \\
\hline
\end{tabular}
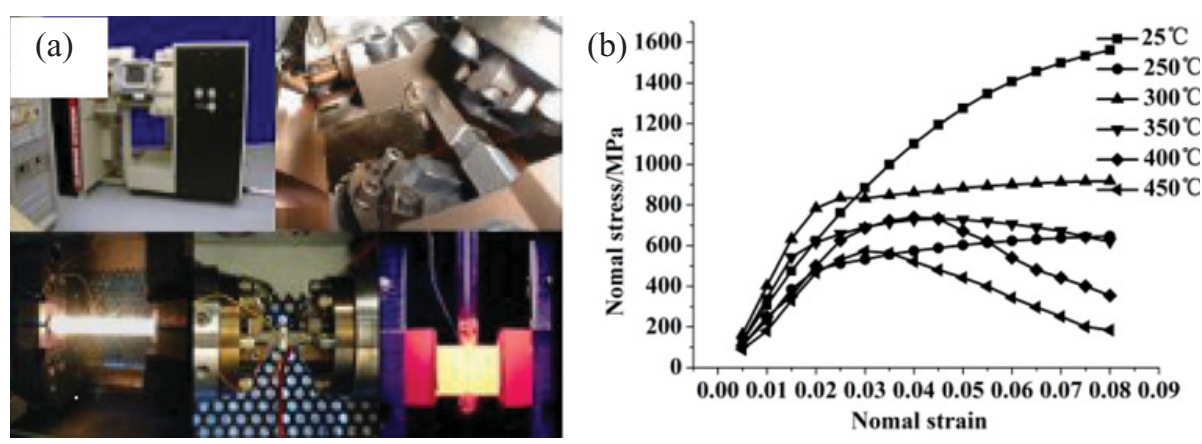

Figure 1. (a) The Gleeble thermal / mechanical simulator; (b) the constitutive relationship of the surfacing layer in different temperature when the PWHT are $550^{\circ} \mathrm{C}$ and $4 \mathrm{~h}$.

The welding velocity was set as $180 \mathrm{~mm} \cdot \mathrm{min}^{-1}$ and the welding inter-pass temperature was chosen as $300 \pm 20^{\circ} \mathrm{C}$. Before welding the substrate was preheated to $350 \pm 25^{\circ} \mathrm{C}$. Chemical compositions for casting-steel substrate (ZG25MnCrNiMo) and surfacing layer (545E) are shown in Table 1 and the mechanical properties are listed in Table 2.

The post weld heat treatment, i.e. tempering process was carried out in an induction heating furnace. The 16 groups of orthogonal experiments selected tempering temperatures are $420^{\circ} \mathrm{C}, 480{ }^{\circ} \mathrm{C}, 550{ }^{\circ} \mathrm{C}$, $600^{\circ} \mathrm{C}$ and holding times are $1 \mathrm{~h}, 2 \mathrm{~h}, 4 \mathrm{~h}$ and $6 \mathrm{~h}$ respectively.

To predict the wear depth of cast-steel dies coated with surfacing layers under different PWHT, it's essential to establish constitutive relationships of the surfacing layers under various PWHT. To gain the constitutive relationships of 16 groups, a series of high temperature (High temperature: $250{ }^{\circ} \mathrm{C}, 300^{\circ} \mathrm{C}$, $350{ }^{\circ} \mathrm{C}, 400{ }^{\circ} \mathrm{C}, 450{ }^{\circ} \mathrm{C}$ ) compression tests were carried out on a Gleeble thermal/mechanical simulator (Gleeble 3500 , heating rate: $10^{\circ} \mathrm{C} / \mathrm{s}$, holding time: $150 \mathrm{~s}$ and amount of compression: $8 \%$ and strain rate: $0.0001 \mathrm{~s}$ ) which can be seen in Fig. 1(a). One group of the constitutive relationships whose tempering temperature and holding time are $550^{\circ} \mathrm{C}$ and $4 \mathrm{~h}$ respectively are in Fig. 1(b). This will be applied in the wear model establishment on the platform DEFORM-3D.

\section{Wear calculation and experimental verification}

\subsection{Wear model established in DEFORM-3D}

To study the wear behavior of the hot forging cast-steel die coated with surfacing layer, the hot forging process of the crankshaft was taken as example. For this crankshaft, there are two operations in the hot forging process, namely the pre-forging process and the finish forging process. Based on the software DEFORM-3D, the thermal-mechanical coupling simulation of the crankshaft forging process was carried out. The main simulation parameters of hot forging process are illustrated in Table 3. 


\section{ICNFT 2015}

Table 3. The main simulation parameters of hot forging process.

\begin{tabular}{|c|c|c|c|c|}
\hline Parameters & $\begin{array}{c}\text { Billet } \\
\text { material }\end{array}$ & $\begin{array}{c}\text { Billet initial forging } \\
\text { temperature }\end{array}$ & $\begin{array}{c}\text { Mold initial } \\
\text { temperature }\end{array}$ & $\begin{array}{c}\text { Forming } \\
\text { speed }\end{array}$ \\
\hline Value & AISI-5140 & $1150^{\circ} \mathrm{C}$ & $250^{\circ} \mathrm{C}$ & $280 \mathrm{~mm} / \mathrm{s}$ \\
\hline
\end{tabular}
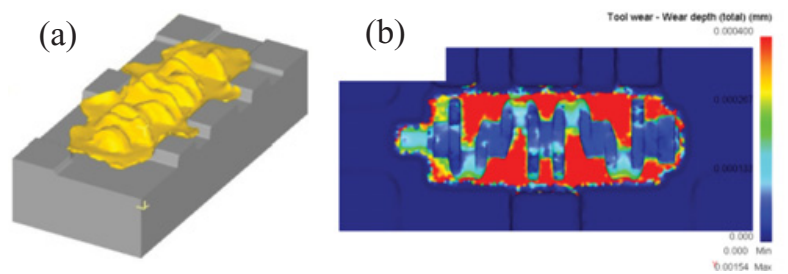

(c)

Figure 2. (a) The finish forging of the crankshaft; (b) Wear depth distribution of the crankshaft; (c) Circumferential coordinate of the Section A-A.
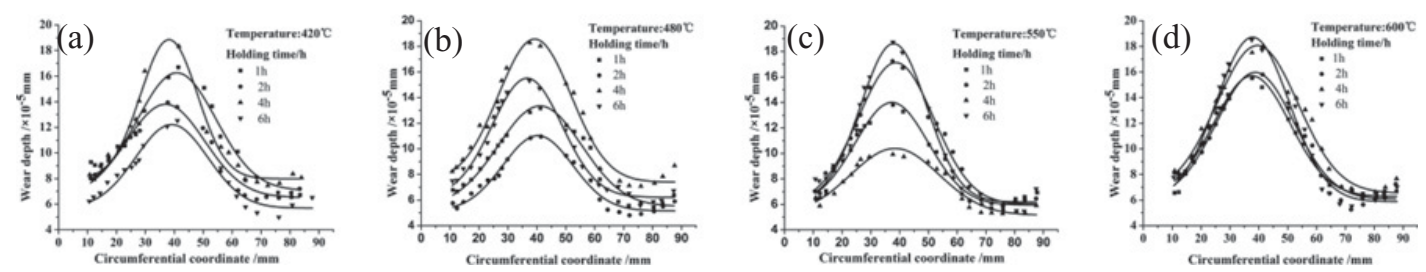

Figure 3. The wear depth prediction of Section A-A in finish forging die with the tempering temperature of: (a) $420{ }^{\circ} \mathrm{C}$, (b) $480^{\circ} \mathrm{C}$, (c) $550{ }^{\circ} \mathrm{C}$ and (d) $600^{\circ} \mathrm{C}$.

The Archard wear model, expressed in Eq. (1), is adopted to simulate the wear behavior of the surfacing layer.

$$
\mathrm{d} w_{i}=\int K \frac{p_{i}^{\mathrm{s}} v_{i}^{\mathrm{b}}}{H^{\mathrm{c}}} \mathrm{d} t .
$$

Where $\mathrm{d} w$ is the wear depth of the die cavity, $P$ and $v$ are the contact pressure and relative sliding velocity respectively. Generally $a$ and $b$ are set as 1 , and $c$ equals to 2 for tool steels simulation [7]. $H$ is the hardness of tool material and $\mathrm{d} t$ is the time increment. $K$ is the wear coefficient and the subscript $i$ refers to the surface node on the forging die. The effect of the different PWHT on the constitutive relationship of the surfacing layer was taken to calculate the wear depth.

The finish die model can be seen in Fig. 2(a). After the wear calculation completed, the wear depth distribution in the finish forging die cavity can be seen in Fig. 2(b). It can be observed that the most severe worn area in the finish forging die cavity locates at the crankshaft front end, Section A-A was chosen to indicate the effect of the PWHT on the wear depth of the surfacing layer. The circumferential coordinate defined to illustrate the wear depth in Section A-A is shown in Fig. 2(c).

Figure 3 shows the wear depth prediction of Section A-A in finish forging die with different PWHT. Under the 16 combinations of the PWHT conditions, the optimal tempering temperature and holding time are $550{ }^{\circ} \mathrm{C}$ and 4 hours respectively. For this optimal PWHT, the die wear depth peak in Section A-A is $9.92 \times 10^{-5} \mathrm{~mm}$ in one forging cycle, which is shown in Fig. 4(b).

\subsection{Wear test discussion}

The material of wear-resistant plate and pressure head are 545E and AISI-5140, which are the same as the surfacing layer and billet material respectively. The contact pressure and relative sliding velocity 
(a)

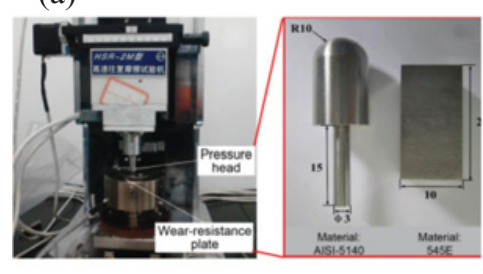

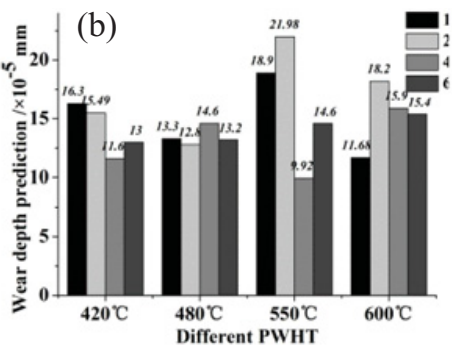

Figure 4. (a) The HSR-2M wear-testing machine and the friction pairs of wear test; (b) Wear depth prediction under different PWHT in one forging cycle; (c) Wear depth of wear test after 100 forging cycle.
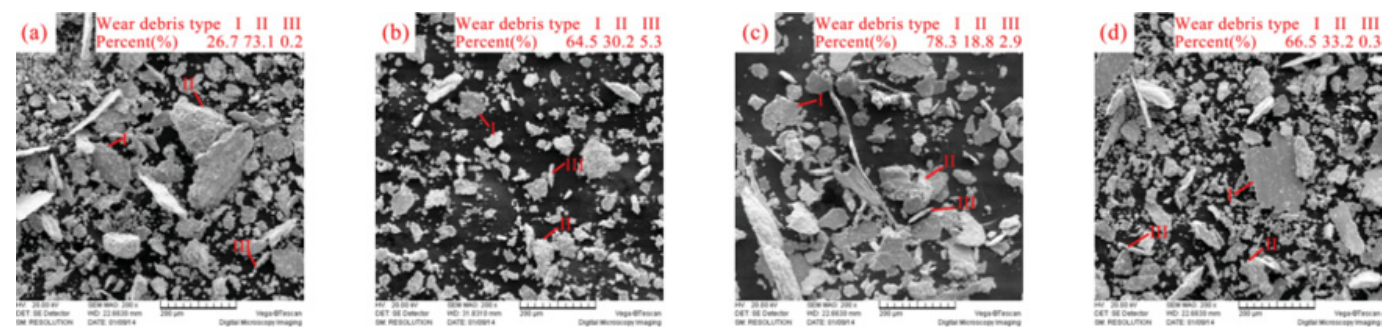

I-Oxidative wear debris II-Adhesive wear debris III-Abrasive wear debris

Figure 5. SEM images of wear debris when tempering temperature is $550{ }^{\circ} \mathrm{C}$ and holding time of: (a) $1 \mathrm{~h}$, (b) $2 \mathrm{~h}$, (c) $4 \mathrm{~h}$ and (d) $6 \mathrm{~h}$.

used in wear test were kept identical to that obtained from FEM simulation of crankshaft hot forging process. The wear test was carried out on HSR-2M wear-testing machine (Temperature: $400{ }^{\circ} \mathrm{C}$, Pressure: 50 N, Speed: 400 r/min, Time: 3 min, Length: $5 \mathrm{~mm}$ ), which is shown in Fig. 4(a).

To verify the wear calculation result in Fig. 4 (b), a series of wear tests were conducted. Figure 4(c) illustrates the wear test result after 100 forging cycles. It can be seen that the optimal tempering temperature and holding time are still $550{ }^{\circ} \mathrm{C}$ and $4 \mathrm{~h}$ respectively and the wear depth of wear-resistance plate is the minimum among all the PWHT, namely $0.00987 \mathrm{~mm}$. What's more, the wear test results show a close agreement with the wear calculation result.

\section{Wear mechanism and strengthening mechanism}

\subsection{Wear test discussion}

In order to gain insight into the wear mechanisms, the wear debris was examined by SEM. The wear debris images corresponding to the optimal PWHT are illustrated in Fig. 5. SEM examinations identified that there are three main types of wear during the wear process, i.e. abrasive wear, adhesive wear and oxidative wear. The adhesive wear debris has a rough surface, an uneven thickness and little oxygen. The shape of abrasive wear debris is banded. The oxidative wear debris has a smooth surface, an even thickness and contains a lot of oxygen. The proportion of the three types wear debris was calculated by MATLAB, and it can be seen that the proportion of oxidative wear debris increases gradually as the holding time extends. Therefore, Oxidative wear mechanism plays a dominant role among all the wear mechanisms. 

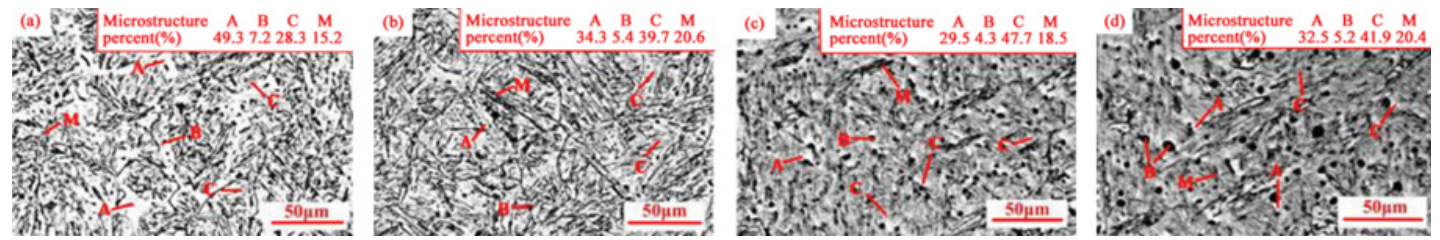

A-Retained Austenite B-Lower Bainite C-Alloy Carbide M-Tempered Marensite

Figure 6. Microstructure of the surfacing layer with the tempering temperature is $550{ }^{\circ} \mathrm{C}$ and holding time of: (a) $1 \mathrm{~h}$, (b) $2 \mathrm{~h}$, (c) $4 \mathrm{~h}$ and (d) $6 \mathrm{~h}$.

\subsection{Microstructure investigation and strengthening mechanism}

To understand the strengthening mechanism of PWHT on the wear resistance of the surfacing layer, the microstructure investigations have been conducted. Specimens from the surfacing layers are etched with $4 \%$ nitric acid solution for 15 seconds. Then, a quantitative metallographic analysis system was used to calculate the percentage of microstructures and the result can be seen in Fig. 6.

It can be seen from Fig. 6(a) that the microstructure of the surfacing layer is composed of tempered martensite, lower bainite, retained austenite and few undissolved alloy carbide when the tempering temperature is $550^{\circ} \mathrm{C}$ and holding time is 1 hour. If the tempering temperature keeps as $550{ }^{\circ} \mathrm{C}$ and the holding time extends to 2 hours, the retained austenite dissolves partly and the alloy carbide precipitation increases a little more, shown in Fig. 6(b). It is obvious in Fig. 6(c) that the retained austenite transforms almost completely and the alloy carbide dispersively distributes in the metallographic structure when the holding time is 4 hours, which is closely related to the wear resistance improvement of the surfacing layer. While the holding time is prolonged to 6 hours, the alloy carbide decreases, which is illustrated in Fig. 6(d). And the dispersivity of alloy carbide decreases, which results in the declining of the wear resistance of the surfacing layer compare to that with holding time of 4 hours. Glaeser [8] studied the relative wear resistance of different microstructures for steel and it can be known that the wear resistance of alloy carbide is pretty good.

\section{Conclusions}

This paper focuses on the effect of Post Weld Heat Treatments (PWHT) on the wear resistance of the surfacing layer in the hot forging process. The following conclusions can be drawn:

(1) The FEM simulation results show that the wear depth of the surfacing layer is significantly affected by the PWHT and the optimal tempering temperature and holding time are $550{ }^{\circ} \mathrm{C}$ and $4 \mathrm{~h}$ respectively. The wear test result shows a good agreement with the FEM simulation result.

(2) SEM examinations identified that there are three main types of wear debris during the wear process and the oxidative wear debris plays a dominant role.

(3) Microstructure investigations on the surfacing layer with different PWHT show that the alloy carbide dispersively distributing in the metallographic structure can improve the wear resistance of the surfacing layer effectively when the tempering temperature and holding time are $550{ }^{\circ} \mathrm{C}$ and $4 \mathrm{~h}$ respectively.

\section{References}

[1] K. Lange, L. Cesr, and M. Geiger, Crip. Ann-manuf. Techn., 41(2), 667-675 (1992)

[2] J.F. Archard, J. Appl. Phys., 24, 981-988 (1953) 


\section{MATEC Web of Conferences}

[3] B. Painter, R. Shivpuri and T. Altan, J. Mater. Process. Technol., 59, 132-143 (1996)

[4] B.A. Behrens and F. Schaefer, J . Mater. Process. Technol., 167, 309-315 (2005)

[5] D.H. Kim, B.M. Kim and C.G. Kang, Finite. Elem. Anal. Des., 41, 1225-1269 (2005)

[6] S. Abachi, M. Akkok and I.M. Gokler, Tribol. Int., 43, 467-473 (2010)

[7] 'DEFORMTM-3D (Version 6.1) User's Manual' (2007)

[8] W.A. Glaeser, Materials for Tribology (Elsevier Science Ltd, 1992) 